\title{
Chemical composition and in vitro digestibility of some selected under-utilized tropical seeds as protein sources in ruminants' diet
}

\author{
Oluwatosin Bode Omotoso * $[$, Mary Oluwafunmilayo Adeduntan 10 and Adebowale Noah Fajemisin
}

\begin{abstract}
Background: The study highlighted the potential of three common and under-utilized tropical leguminous seeds (Tomentosa nilotica, Dioclea reflexa and Monodora myristica) to be used as supplementary feed to ruminant livestock. These seeds (their plants inclusive) are valuable sources of food and medicine for the prevention of illness and maintenance of human health. The medicinal properties of these seeds include antimicrobial, anti-inflammatory, anti-oxidant and immuno-stimulant. Trypsin inhibitors, which are common anti-nutritional factors in legumes and for monogastric animals, do not exert adverse effects in ruminants because they are degraded in the rumen. Hence, the crux of this study is to examine the effect of processing methods on the nutritional composition (proximate, fibre fractions, minerals, anti-nutrients) and in vitro digestibility of Tomentosa nilotica, Dioclea reflexa and Monodora myristica seeds and their suitability as feedstuff (protein sources) in small ruminant feed, particularly during off-season.
\end{abstract}

Results: From the results, raw Tomentosa nilotica and Monodora myristica have the highest crude protein (30.35\% CP) and fat $(22.40 \% \mathrm{EE})$, respectively. It is noteworthy that roasting best improve the mineral and significantly reduce the anti-nutrients observed in this study better compared to boiling and soaking methods. The highest organic matter digestibility, short-chain fatty acids, metabolizable energy and in vitro dry matter digestibility values were obtained in Dioclea reflexa compared to other test seeds. Roasting best improved the nutritive values, while Dioclea reflexa seed was rated highest for all the nutritional attributes and in vitro digestibility.

Conclusions: Dioclea reflexa could be incorporated in ruminants' diet as protein source, particularly during the offseason, for improved ruminant production in Nigeria. However, in vivo study is therefore recommended to validate this report.

Keywords: In vitro digestibility, Methane, Processing, Protein, Ruminants, Tropical seeds

\section{Background}

Leguminous plants comprise many species, whose seeds differ considerably in their chemical composition and nutritive value. In the tropics, particularly in Nigeria, a number of them are grossly under-utilized. Some of

\footnotetext{
*Correspondence: obomotoso@futa.edu.ng; tos2bod@yahoo.com Department of Animal Production and Health, School of Agriculture and Agricultural Technology, Federal University of Technology, P.M.B. 704, Akure, Nigeria
}

which are Tomentosa nilotica (Acacia), Dioclea reflexa (marble plant), Monodora myristica (African nutmeg). These plants impact the environment through soil reclamation, soil enrichment, protection against fire and wind, and as a haven for biodiversity and ornament. The medicinal properties include improved digestibility, antimicrobial, anti-inflammatory, anti-oxidant and immuno-stimulant (Eugenius et al. 2017). They are high in nutritional values. Hence, the plants and their seeds are widely used as sources of protein. Besides protein, 
the seeds provide many other important components, such as minerals and B-complex vitamins and have other vital health protective compounds-phenolics, inositol phosphates and oligosaccharides. Meanwhile, minerals are known to play important metabolic and physiological functions in living cells and are needed by the body to trigger the thousands of chemical reactions necessary to maintain good health (Vaclavic and Christian 2008). However, leguminous seeds contain undesirable biologically active substances, including anti-nutritional factors (ANFs)-tannins, alkaloids, protease inhibitors and others. In addition, feeds differ in their methane production potentiality depending on chemical composition, and plant metabolites present in them (Patra 2012; Eugenius et al. 2017). These plant metabolites/anti-nutritional factors (ANFs) are substances which either by themselves or through their metabolic products, interfere with feed utilization, affect the health and production of animal or which act to reduce nutrients intake, digestion, absorption and utilization and may produce other adverse effects (Akande et al. 2010; Omotoso 2018). Trypsin inhibitors, which are ANFs for monogastric animals, do not exert adverse effects in ruminants because they are degraded in the rumen. Generally, tannin induces negative responses such as astringency, bitterness or unpleasant taste when consumed (Brown 2008; Huang et al. 2018; Ramos et al. 2020). Tannins and phytates have been reported to negatively affect the bioavailability of minerals such as iron when consumed in large quantities (Clemens 2014) by forming insoluble anti-nutritional mineral complexes before absorption (Gorczyca et al. 2013). Meanwhile in ruminants, methane production in the rumen represents $2-12 \%$ loss of feed energy (Wanapat et al. 2015) decreasing the metabolizable energy content of feeds. In addition, production of greenhouse gases from animals and their impact on climate changes are a major concern worldwide (Martin et al. 2010; Gerber et al. 2013). Methane is the second highest anthropogenic greenhouse gas after carbon dioxide, which contributes to the problems of global warming and climate change (Tubiello et al. 2011). Enteric methane is normally produced during the fermentation of feeds mostly in the rumen by hydrogenotrophic methanogenic archaea, which results in the inefficient conversion of potential energy of feeds into methane that is not utilized by ruminants (Pal et al. 2015). Reduction in enteric methane emission enhances the efficiency of nutrient utilization and augments productivity and also reduces methane impact on global warming. Hence, the crux of this study is to determine the effect of processing methods on the nutritional composition and in vitro digestibility of Tomentosa nilotica, Dioclea reflexa and Monodora myristica seeds and their suitability as feedstuff for small ruminant, particularly during off-season.

\section{Methods \\ Experimental site}

The research work was carried out at the Ruminant Unit of the Livestock Section, Teaching and Research Farm, while laboratory analysis was carried out at Nutritional Laboratory of the Department of Animal Production and Health, Federal University of Technology, Akure (FUTA) located on Latitude $7^{\circ} 15^{\prime \prime} \mathrm{N}$ and Longitude $5^{\circ} 15^{\prime \prime} \mathrm{E}$ (Ajibade et al. 2014).

\section{Tomentosa nilotica, Dioclea reflexa and Monodora myristica seed collection}

Matured Tomentosa nilotica pods were harvested within the campus of the Federal University of Technology, Akure, while the seeds of Dioclea reflexa and Monodora myristica were sourced from the villages around Akure metropolis, Ondo State, Nigeria. The seeds were screened and were subjected to three processing methods (boiling with water at $100{ }^{\circ} \mathrm{C}$ for $10 \mathrm{~min}$, roasting inside frying pan till the seeds are crispy and turned golden brown and soaked in water for $24 \mathrm{~h}$, in air-tight container thereafter, the filtrate were decanted and sun-dried) to enhance the nutritive values and facilitate easy grinding to form the respective seed meals.

\section{Chemical analysis}

The samples were analyzed for proximate, minerals and antinutrients composition using standard procedures of AOAC (2011) methods. Neutral detergent fibre (NDF) was determined by the method of Van Soest et al. (1991), whereas acid detergent fibre (ADF) and acid detergent lignin (ADL) were analyzed according to Van Soest and Robertson (1985). All analyses were carried out in triplicate.

\section{In vitro degradability trial}

In vitro degradability study of the raw and differently processed seed meals was carried out using in vitro gas production techniques according to the modified methods of Babayemi and Bamikole (2006). Rumen liquor was collected from matured goat-bucks after been fed with grass and concentrate diet for two weeks to activate the rumen microbes activities. The rumen liquor/fluid was collected using a suction tube into the thermo-flask that had been pre-warmed to a temperature of $39{ }^{\circ} \mathrm{C}$. Buffer solution prepared was the McDougall's solution which consist solution $(\mathrm{g} / \mathrm{l})$ of 9.8 $\mathrm{NaHCO}_{3}+2.77 \mathrm{Na}_{2} \mathrm{HPO}_{4}+0.57 \mathrm{KCl}+0.47 \mathrm{NaCl}+2.16$ $\mathrm{MgSO}_{3} \cdot 7 \mathrm{H}_{2} \mathrm{O}+16 \mathrm{CaCl}_{2} \cdot 2 \mathrm{H}_{2} \mathrm{O}$ and mixed with rumen liquor at 1:4 (v/v) under continuous flushing with $\mathrm{CO}_{2}$ 
to minimize changes in microbial populations and to avoid $\mathrm{O}_{2}$ contamination for the incubation. Incubation procedure was carried out using $120 \mathrm{ml}$ calibrated transparent plastic syringes with fitted silicon tube.

The sample weighing $200 \mathrm{mg}(n=3)$ was carefully dropped into syringes and thereafter, $30 \mathrm{ml}$ each of the inoculum containing cheese cloth strained rumen liquor and buffer solution. The syringe was tapped and pushed upward by the piston in order to completely eliminate air in the inoculum. The silicon tube fitted to the syringe was then tightened by a metal clip so as to prevent escape of gas. Incubation procedure was carried out using $50 \mathrm{ml}$ calibrated transparent plastic syringes with fitted silicon piston. The syringe was covered and pushed upward by a piston in order to get rid of air completely in the inoculums. Incubation was carried at $39 \pm 1{ }^{\circ} \mathrm{C}$, and the gas production volume was measured at $0,3,6,9,12,16,18,21$ and $24 \mathrm{~h}$. At the end of the termination hour, $4 \mathrm{ml}$ of $\mathrm{NaOH}(10 \mathrm{M})$ was introduced to estimate the methane production according to Fievez et al. (2005), metabolizable energy (ME), organic matter digestibility (OMD) and short-chain fatty acids (SCFA) were estimated according to the methods of Menke and Steingass (1988). The average volumes of gas produced from the blanks were deducted from the total volume of gas produced per sample. The following were calculated as: $\quad \mathrm{ME} \quad(\mathrm{MJ} / \mathrm{KgDM})=2.20+0.136 \mathrm{GV}+0.057 \mathrm{CP}+0.0$ 029 CF; OMD $(\%)=14.88+889 \mathrm{GV}+0.45 \mathrm{CP}+0.651$ $\mathrm{XA}$; SCFA $=0.0239 \mathrm{~V}-0.0601$. Where; GV, CP CF and $\mathrm{XA}$ are total gas volume, crude protein, crude fibre and ash, respectively. The in vitro dry matter digestibility (IVDMD) was determined with the method of McDonald (1979).

\section{Experimental design and Statistical analysis}

The experimental layout was completely randomized design, and all data generated were subjected to analysis of variance (ANOVA), and the treatment means were compared by the methods of Duncan's Multiple Range Test using SAS (2010) version 9.3. Significant difference was set at $p<0.05$.

\section{Results}

Chemical composition of raw and differently processed Tomentosa nilotica, Dioclea reflexa and Monodora myristica seed meals

Table 1 presents the chemical composition of raw and differently treated seeds of Tomentosa nilotica, Dioclea reflexa and Monodora myristica. The treatments/ processing techniques-boiling, soaking and roasting, had significant $(p<0.05)$ influence on the nutritive compositions on the seeds. Raw/unprocessed Monodora

Table 1 Chemical composition (g/100g DM) of raw and differently processed Tomentosa nilotica, Dioclea reflexa and Monodora myristica seed meals

\begin{tabular}{|c|c|c|c|c|c|c|c|c|}
\hline Seed & $\begin{array}{l}\text { Processing } \\
\text { methods }\end{array}$ & Dry matter & Crude protein & Crude fibre & Fat & $\begin{array}{l}\text { Neutral } \\
\text { detergent fibre }\end{array}$ & $\begin{array}{l}\text { Acid detergent } \\
\text { fibre }\end{array}$ & $\begin{array}{l}\text { Acid detergent } \\
\text { lignin }\end{array}$ \\
\hline $\begin{array}{l}\text { Tomentosa } \\
\text { nilotica }\end{array}$ & Raw & $88.16 \pm 0.28^{a}$ & $30.35 \pm 0.67^{\mathrm{a}}$ & $12.66 \pm 0.48^{\mathrm{ab}}$ & $21.67 \pm 0.98^{b}$ & $30.48 \pm 0.08^{b}$ & $20.10 \pm 0.76^{b}$ & $9.62 \pm 0.78^{b}$ \\
\hline Dioclea reflexa & & $84.40 \pm 0.51^{b}$ & $18.97 \pm 0.59^{b}$ & $13.70 \pm 0.32^{\mathrm{a}}$ & $22.30 \pm 0.01^{\mathrm{a}}$ & $29.60 \pm 1.18^{b}$ & $20.75 \pm 0.61^{b}$ & $10.10 \pm 1.98^{\mathrm{a}}$ \\
\hline $\begin{array}{r}\text { Monodora } \\
\text { myristica }\end{array}$ & & $89.20 \pm 0.33^{a}$ & $16.37 \pm 0.85^{c}$ & $11.00 \pm 0.18^{b}$ & $22.40 \pm 0.07^{a}$ & $40.00 \pm 0.50^{\mathrm{a}}$ & $25.30 \pm 0.78^{a}$ & $9.65 \pm 0.52^{b}$ \\
\hline $\begin{array}{c}\text { Tomentosa } \\
\text { nilotica }\end{array}$ & Boiled & $89.21 \pm 0.58^{a}$ & $32.03 \pm 0.22^{a}$ & $9.20 \pm 0.08^{c}$ & $19.00 \pm 0.05^{\mathrm{ab}}$ & $39.83 \pm 0.88^{b}$ & $34.30 \pm 4.74^{a}$ & $17.50 \pm 2.42^{\mathrm{a}}$ \\
\hline Dioclea reflexa & & $87.03 \pm 0.33^{b}$ & $20.05 \pm 0.67^{b}$ & $12.20 \pm 0.07^{\mathrm{a}}$ & $18.20 \pm 0.18^{b}$ & $34.33 \pm 0.82^{c}$ & $23.98 \pm 0.88^{b}$ & $16.94 \pm 3.51^{b}$ \\
\hline $\begin{array}{r}\text { Monodora } \\
\text { myristica }\end{array}$ & & $89.90 \pm 0.42^{\mathrm{a}}$ & $17.90 \pm 0.33^{c}$ & $10.05 \pm 0.13^{b}$ & $19.50 \pm 0.08^{\mathrm{a}}$ & $50.20 \pm 0.28^{\mathrm{a}}$ & $33.95 \pm 2.56^{a}$ & $13.04 \pm 1.08^{c}$ \\
\hline $\begin{array}{c}\text { Tomentosa } \\
\text { nilotica }\end{array}$ & Soaked & $81.30 \pm 0.54^{c}$ & $27.58 \pm 1.02^{\mathrm{a}}$ & $11.00 \pm 0.21^{b}$ & $20.10 \pm 0.38^{a}$ & $36.02 \pm 0.66^{b}$ & $20.10 \pm 1.53^{b}$ & $11.20 \pm 0.15^{b}$ \\
\hline Dioclea reflexa & & $89.20 \pm 0.48^{a}$ & $18.20 \pm 2.18^{b}$ & $11.70 \pm 0.51^{\mathrm{a}}$ & $18.02 \pm 0.28^{b}$ & $35.20 \pm 0.58^{b}$ & $20.75 \pm 0.88^{b}$ & $11.30 \pm 0.38^{b}$ \\
\hline $\begin{array}{l}\text { Monodora } \\
\text { myristica }\end{array}$ & & $83.60 \pm 0.51^{b}$ & $14.70 \pm 1.11^{c}$ & $9.10 \pm 0.35^{c}$ & $18.95 \pm 0.22^{b}$ & $47.20 \pm 0.54^{\mathrm{a}}$ & $25.30 \pm 0.38^{\mathrm{a}}$ & $14.00 \pm 0.47^{\mathrm{a}}$ \\
\hline $\begin{array}{l}\text { Tomentosa } \\
\text { nilotica }\end{array}$ & Roasted & $90.90 \pm 0.57^{a}$ & $33.23 \pm 0.97^{\mathrm{a}}$ & $13.00 \pm 0.18^{b}$ & $16.60 \pm 0.58^{b}$ & $38.90 \pm 0.91^{b}$ & $26.00 \pm 0.78^{b}$ & $12.86 \pm 0.16^{b}$ \\
\hline Dioclea reflexa & & $86.50 \pm 0.34^{b}$ & $22.96 \pm 0.58^{b}$ & $13.00 \pm 0.61^{b}$ & $16.10 \pm 0.55^{b}$ & $36.10 \pm 0.85^{c}$ & $24.90 \pm 0.98^{c}$ & $11.02 \pm 0.51^{\mathrm{c}}$ \\
\hline \multirow{2}{*}{$\begin{array}{l}\text { Monodora } \\
\text { myristica }\end{array}$} & & $90.50 \pm 0.18^{\mathrm{a}}$ & $18.60 \pm 0.76^{c}$ & $13.90 \pm 0.55^{\mathrm{a}}$ & $18.00 \pm 0.48^{\mathrm{a}}$ & $49.20 \pm 0.48^{\mathrm{a}}$ & $33.05 \pm 0.54^{\mathrm{a}}$ & $15.90 \pm 0.33^{\mathrm{a}}$ \\
\hline & $p$ value & $<0.01$ & $<0.01$ & $<0.01$ & $<0.01$ & $<0.01$ & $<0.01$ & $<0.01$ \\
\hline
\end{tabular}

\footnotetext{
$a, b, c$ Means within the same row with different superscripts are significantly $(p<0.05)$ different. $n=3$
} 
Table 2 Mineral and anti-nutrient compositions (g/100g DM) of raw and differently processed Tomentosa nilotica, Dioclea reflexa and Monodora myristica seed meals

\begin{tabular}{|c|c|c|c|c|c|c|c|}
\hline Seeds & $\begin{array}{l}\text { Processing } \\
\text { methods }\end{array}$ & Calcium & Phosphorus & Sodium & Alkaloid & Tannin & Phytate \\
\hline Tomentosa nilotica & \multirow[t]{3}{*}{ Raw } & $2.20 \pm 0.08^{\mathrm{a}}$ & $1.10 \pm 0.05^{\mathrm{a}}$ & $2.70 \pm 0.15^{\mathrm{a}}$ & $4.40 \pm 0.89^{\mathrm{a}}$ & $3.51 \pm 0.05^{b}$ & $4.18 \pm 0.18^{a}$ \\
\hline Dioclea reflexa & & $1.70 \pm 0.02^{b}$ & $0.80 \pm 0.04^{b}$ & $0.30 \pm 0.21^{b}$ & $2.00 \pm 0.04^{c}$ & $3.75 \pm 0.24^{b}$ & $4.67 \pm 0.15^{a}$ \\
\hline Monodora myristica & & $1.63 \pm 0.01^{b}$ & $0.80 \pm 0.04^{b}$ & $0.36 \pm 0.49^{b}$ & $4.08 \pm 0.16^{b}$ & $4.63 \pm 0.19^{\mathrm{a}}$ & $3.73 \pm 0.09^{b}$ \\
\hline Tomentosa nilotica & \multirow[t]{3}{*}{ Boiled } & $2.50 \pm 0.50^{\mathrm{a}}$ & $1.95 \pm 0.13^{\mathrm{a}}$ & $4.10 \pm 0.23^{\mathrm{a}}$ & $2.06 \pm 0.27^{b}$ & $1.53 \pm 0.30^{b}$ & $2.04 \pm 0.21^{\mathrm{a}}$ \\
\hline Dioclea reflexa & & $1.60 \pm 0.00^{b}$ & $1.30 \pm 0.19^{b}$ & $2.80 \pm 0.14^{b}$ & $1.80 \pm 0.61^{c}$ & $1.76 \pm 0.17^{b}$ & $2.02 \pm 0.06^{\mathrm{a}}$ \\
\hline Monodora myristica & & $1.70 \pm 0.01^{b}$ & $1.25 \pm 0.01^{b}$ & $2.70 \pm 0.02^{b}$ & $3.98 \pm 0.32^{\mathrm{a}}$ & $2.66 \pm 0.33^{\mathrm{a}}$ & $1.71 \pm 0.03^{b}$ \\
\hline Tomentosa nilotica & \multirow[t]{3}{*}{ Soaked } & $2.60 \pm 0.18^{a}$ & $1.43 \pm 0.08^{\mathrm{a}}$ & $3.90 \pm 0.16^{\mathrm{a}}$ & $2.97 \pm 0.12^{\mathrm{a}}$ & $0.53 \pm 0.00^{b}$ & $1.50 \pm 0.11^{\mathrm{a}}$ \\
\hline Dioclea reflexa & & $2.06 \pm 0.68^{b}$ & $1.50 \pm 0.15^{\mathrm{a}}$ & $2.06 \pm 0.05^{b}$ & $0.80 \pm 0.18^{b}$ & $0.78 \pm 0.01^{\mathrm{a}}$ & $1.02 \pm 0.09^{b}$ \\
\hline Monodora myristica & & $2.20 \pm 0.12^{\mathrm{ab}}$ & $1.10 \pm 0.11^{b}$ & $2.20 \pm 0.15^{b}$ & $2.90 \pm 0.58^{\mathrm{a}}$ & $0.60 \pm 0.01^{b}$ & $1.08 \pm 0.08^{b}$ \\
\hline Tomentosa nilotica & \multirow[t]{3}{*}{ Roasted } & $2.90 \pm 0.02^{\mathrm{a}}$ & $1.95 \pm 0.11^{\mathrm{a}}$ & $2.30 \pm 0.01^{\mathrm{a}}$ & $2.80 \pm 0.55^{\mathrm{a}}$ & $2.06 \pm 0.03^{b}$ & $2.83 \pm 0.08^{a}$ \\
\hline Dioclea reflexa & & $2.34 \pm 0.03^{b}$ & $1.67 \pm 0.15^{b}$ & $1.02 \pm 0.00^{\mathrm{b}}$ & $1.05 \pm 0.49^{b}$ & $2.63 \pm 0.13^{\mathrm{a}}$ & $2.86 \pm 0.03^{\mathrm{a}}$ \\
\hline \multirow[t]{2}{*}{ Monodora myristica } & & $2.25 \pm 0.14^{b}$ & $1.13 \pm 0.05^{c}$ & $2.05 \pm 0.03^{\mathrm{ab}}$ & $2.63 \pm 0.33^{\mathrm{a}}$ & $2.62 \pm 0.01^{\mathrm{a}}$ & $1.97 \pm 0.02^{b}$ \\
\hline & $p$ value & $<0.001$ & $<0.001$ & $<0.001$ & $<0.001$ & $<0.001$ & $<0.001$ \\
\hline
\end{tabular}

$a, b, c$ Means within the same row with different superscripts are significantly $(p<0.05)$ different. $n=3$

myristica seed had high dry matter $(89.20 \mathrm{~g} / 100 \mathrm{~g} \mathrm{DM})$, fat $(22.40 \mathrm{~g} / 100 \mathrm{~g})$, neutral detergent fibre $(40.00 \mathrm{~g} / 100 \mathrm{~g})$, acid detergent fibre $(25.30 \mathrm{~g} / 100 \mathrm{~g})$, while raw Tomentosa had the highest crude protein $(30.35 \mathrm{~g} / 100 \mathrm{~g})$. The lipid content of Monodora myristica (40.60 g/100g DM) is significantly higher than other test seeds. The overall nutritive value of Dioclea reflexa seed was best improved by roasting technique followed by Tomentosa nilotica seed.

The mineral and anti-nutrients composition of raw and differently processed seeds of Tomentosa nilotica, Dioclea reflexa and Monodora myristica are presented in Table 2. There were significant $(p<0.05)$ differences among the parameters observed. The $\mathrm{Ca}, \mathrm{P}$ and $\mathrm{Na}$ contents of T. nilotica were higher compared to other test seeds. It is noteworthy that roasting best improve the mineral and significantly reduce the anti-nutrients observed in this study compared to boiling and soaking methods. The $\mathrm{Ca}, \mathrm{P}$ and $\mathrm{Na}$ concentrations were highest in raw $T$. nilotica seed and progressively and linearly improved by the treatments. Boiled and roasted seeds of T. nilotica had similar and highest P contents (1.95 g/100g DM). The alkaloid, tannin and phytate concentrations of the seeds were drastically reduced with roasting techniques compared to other treatments. Figures 1 and 2 show the relationship that exist between the in vitro digestibility and methane gas production; that of in vitro methane and percentage of tannin in the seeds as it may affect protein utilization, respectively.

The highest in vitro characteristics (OMD, SCFA, ME and IVDMD) values were obtained in Dioclea reflexa seeds for all the processing methods adapted

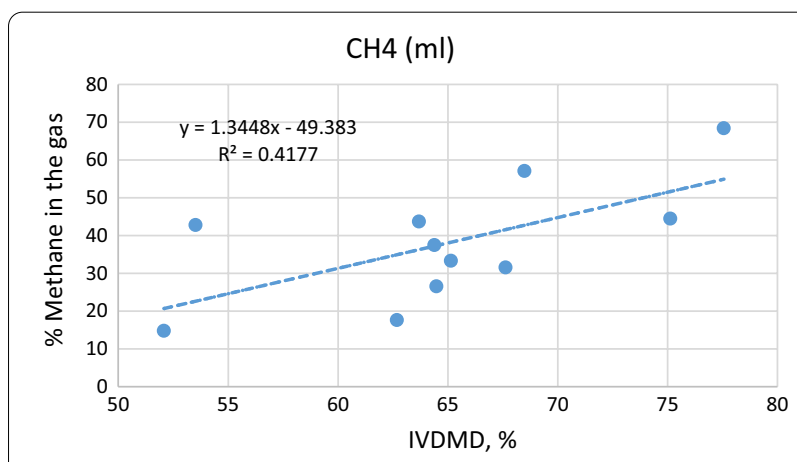

Fig. 1 Relationship between in vitro digestibility and the percentage of methane in the gas

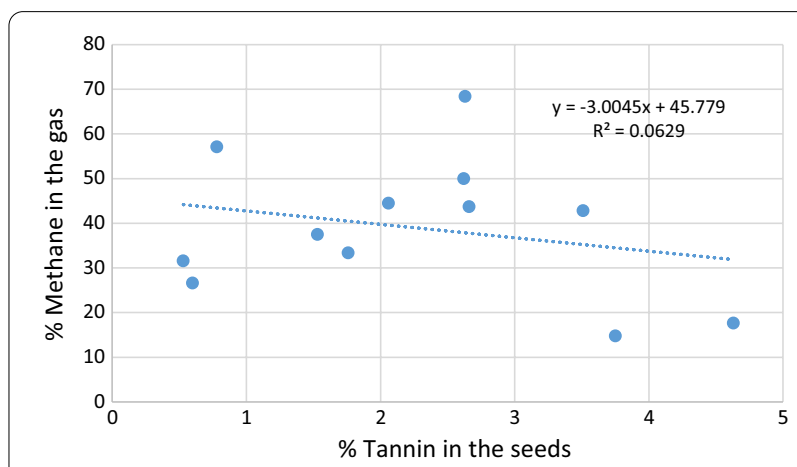

Fig. 2 Relationship between in vitro methane and percentage of tannin in the seeds 
(Table 3). From the table, there were significant $(p<0.05)$ differences among all the in vitro characteristics parameters determined. For the raw seeds, Dioclea reflexa had the highest $(51.47 \%)$ organic matter digestibility (OMD) value and least in Monodora myristica $(32.79 \%)$ which had statistically $(p>0.05)$ similar value with Tomentosa nilotica (35.72\%) but differed numerically. However, the values increased progressively with the treatment and $D$. reflexa had the highest OMD value (61.74\%) with soaking technique. The short-chain fatty acids (SCFA) content ranged between $0.04 \mu \mathrm{mol} / 200 \mathrm{mg} \mathrm{DM}$ (Monodora myristica / roasted) and $0.78 \mu \mathrm{mol} / 200 \mathrm{mg}$ DM (Dioclea reflexa / soaked). However, the Metabolizable energy (ME) ranged between $3.94 \mathrm{MJ} / \mathrm{kg}$ DM (Monodora myristica / raw) to $8.64 \mathrm{MJ} /$ kg DM (Dioclea reflexa / soaked). The highest methane $(4.67 \mathrm{ml})$ and carbon dioxide gases $(9.33 \mathrm{ml})$ generated were obtained in Dioclea reflexa in boiled sample, while in vitro dry matter digestibility (IVDMD) of roasted Dioclea reflexa was the highest (77.56\%).

\section{Discussion}

The analyzed seeds were characterized by high dry matter (DM) content, i.e. over $80 \mathrm{~g} / 100 \mathrm{~g}$ DM (Table 1). Similar high DM content was reported by Eugenius et al. (2017) for yellow and Andean lupine seeds. An indication that microbial activity will be reduced to a minimum and thus, can be stored for a long period. Also, the DM and CF could be handled by ruminants and would encourage rumination if fed to ruminants as they would stay longer in the stomach (gut fill) and probably increase the villi length which consequently enhance the growth performance. The seeds of the legume plants were characterized by high protein content, in particular the Tomentosa nilotica (30.35 g/100g DM). Lower value $19.00 \mathrm{~g} / 100 \mathrm{~g}$ DM crude protein has been reported for Acacia nilotica seed (Heuze et al. 2016). The disparity could be attributed to the species of the Tomentosa and soil nutrient profile on which they were grown. The $\mathrm{CP}$ contents were adequate to enact the activities of the rumen microbes. A significant reduction in nutrient values was noticed with the soaking methods compared to roasting. This could be attributed to the washing away of some nutrients (leaching) in the process of decanting the filtrate. The high lipid content of Monodora myristica is indicative of the fact that these seeds proved to be oilbearing species and are good source of flavour since they are rich in essential oil and also suggests possible sources of oil-soluble vitamins. Meanwhile, the dietary fibre fractions are essential for the digestion.

NRC (2007) suggested that calcium contents in the range of 0.2 and $0.82 \%$ of DM are adequate for lamb and sheep at gestation and lactation stages, respectively, while 0.16 and $0.38 \%$ of DM are adequate for lamb and sheep at production stages and $\mathrm{Na}$ contents in the range 1 to $4 \mathrm{~g} / \mathrm{kg} \mathrm{DM}$ at most production stages. The highest $\mathrm{Ca}$ and $\mathrm{P}$ contents in the roasted seeds samples imply that there absorption would prevent bone diseases such as rickets, osteoporosis and osteomalacia. Notably, calcium also enhances the effective absorption of iron in the system (Adeyeye 2013). Anti-nutritional substances comprise compounds that significantly diminish the

Table 3 In vitro characteristics of raw and differently processed Tomentosa nilotica, Dioclea reflexa and Monodora myristica seed meals

\begin{tabular}{|c|c|c|c|c|c|c|c|}
\hline Seed & $\begin{array}{l}\text { Processing } \\
\text { methods }\end{array}$ & OMD (\%) & $\mathrm{SCFA}(\mu \mathrm{m})$ & ME (Kcal/g) & $\mathrm{CH}_{4}(\mathrm{ml})$ & $\mathrm{CO}_{2}(\mathrm{ml})$ & IVDMD (\%) \\
\hline Tomentosa nilotica & \multirow[t]{3}{*}{ Raw } & $35.72 \pm 0.78^{b}$ & $0.05 \pm 0.02^{b}$ & $4.66 \pm 0.12^{b}$ & $2.00 \pm 0.00^{\mathrm{a}}$ & $2.67 \pm 0.88^{b}$ & $53.52 \pm 1.15^{b}$ \\
\hline Dioclea reflexa & & $51.47 \pm 0.89^{a}$ & $0.54 \pm 0.02^{\mathrm{a}}$ & $6.72 \pm 0.14^{\mathrm{a}}$ & $1.33 \pm 0.67^{b}$ & $7.67 \pm 1.67^{\mathrm{a}}$ & $52.08 \pm 0.52^{a}$ \\
\hline Monodora myristica & & $32.79 \pm 1.48^{b}$ & $0.08 \pm 0.04^{b}$ & $3.94 \pm 0.23^{c}$ & $1.00 \pm 0.00^{b}$ & $4.67 \pm 1.67^{b}$ & $62.68 \pm 0.57^{c}$ \\
\hline Tomentosa nilotica & \multirow[t]{3}{*}{ Boiled } & $48.48 \pm 7.51^{\mathrm{a}}$ & $0.35 \pm 0.20^{a}$ & $6.67 \pm 1.15^{\mathrm{a}}$ & $4.00 \pm 6.0^{a}$ & $6.67 \pm 3.28^{b}$ & $64.39 \pm 0.81^{a}$ \\
\hline Dioclea reflexa & & $57.19 \pm 3.88^{a}$ & $0.49 \pm 0.10^{a}$ & $6.68 \pm 0.59^{a}$ & $4.67 \pm 0.33^{b}$ & $9.33 \pm 4.9^{a}$ & $65.14 \pm 0.58^{b}$ \\
\hline Monodora myristica & & $39.56 \pm 2.07^{b}$ & $0.07 \pm 0.06^{b}$ & $4.07 \pm 0.32^{b}$ & $2.33 \pm 0.67^{c}$ & $3.00 \pm 2.08^{c}$ & $63.69 \pm 0.98^{c}$ \\
\hline Tomentosa nilotica & \multirow[t]{3}{*}{ Soaked } & $39.43 \pm 1.43^{b}$ & $0.09 \pm 0.03^{b}$ & $5.17 \pm 0.17^{b}$ & $2.00 \pm 0.00^{a b}$ & $4.33 \pm 1.20^{b}$ & $67.62 \pm 0.58^{a}$ \\
\hline Dioclea reflexa & & $61.74 \pm 6.94^{\mathrm{a}}$ & $0.78 \pm 0.19^{a}$ & $8.64 \pm 1.06^{a}$ & $4.00 \pm 1.00^{\mathrm{a}}$ & $3.00 \pm 6.93^{a}$ & $68.49 \pm 2.08^{a}$ \\
\hline Monodora myristica & & $40.77 \pm 1.03^{b}$ & $0.05 \pm 0.03^{b}$ & $4.09 \pm 0.16^{c}$ & $1.33 \pm 0.33^{b}$ & $3.67 \pm 0.88^{c}$ & $64.48 \pm 1.25^{c}$ \\
\hline Tomentosa nilotica & \multirow[t]{3}{*}{ Roasted } & $54.06 \pm 0.00^{b}$ & $0.08 \pm 0.00^{b}$ & $5.23 \pm 0.00^{b}$ & $2.67 \pm 0.33^{b}$ & $3.33 \pm 0.33^{b}$ & $75.12 \pm 2.18^{b}$ \\
\hline Dioclea reflexa & & $60.93 \pm 0.59^{a}$ & $0.69 \pm 0.02^{\mathrm{a}}$ & $7.87 \pm 0.09^{a}$ & $4.33 \pm 0.33^{\mathrm{a}}$ & $2.00 \pm 0.58^{\mathrm{a}}$ & $77.56 \pm 4.57^{\mathrm{a}}$ \\
\hline \multirow[t]{2}{*}{ Monodora myristica } & & $43.98 \pm 0.51^{c}$ & $0.04 \pm 0.01^{c}$ & $3.98 \pm 0.08^{c}$ & $2.00 \pm 0.00^{b}$ & $2.00 \pm 0.58^{b}$ & $74.39 \pm 1.58^{c}$ \\
\hline & $p$ value & $<0.01$ & $<0.01$ & $<0.01$ & $<0.01$ & $<0.01$ & $<0.01$ \\
\hline
\end{tabular}

OMD organic matter digestibility, SCFA short-chain fatty acids, ME metabolizable energy, IVDMD in vitro dry matter digestibility

$\mathrm{a}, \mathrm{b}, \mathrm{c}$ Means within the same row with different superscripts are significantly $(p<0.05)$ different. $n=3$ 
nutritional value of leguminous plants and hinder nutrient absorption (Table 2). Tannins are polyphenolic compounds capable of forming stable complexes with proteins, minerals and vitamins $A$ and $B_{12}$, which results in deterioration of the digestibility and availability of nutrients (Ramos et al. 2020). Their negative impact is reflected not only in deterioration of protein digestibility through complexation thereof, but also in blocking the activity of proteolytic enzymes. The three processing methods implored in this study lowered the antinutrients to a tolerable level that can easily be degraded in the rumen, if fed to ruminants as a feedstuff/ingredient in a complete concentrate diet, and thus nutrient absorption (vitamin D, iron, calcium and phosphorus) and general growth performance would not be hindered. The quantity of tannin of the roasted and soaked seed samples was lower than $5 \%$ that was reported to adversely affects dry matter intake and digestibility in ruminants (Księżak and Bojarszczuk 2014). Consequently, the astringent taste may lead to more water consumption by the animals, if fed. However, Huang et al. (2018) opined that the effect of tannins may depend on the type of tannins consumed or the chemical structure and molecular weight. The strong relationships between in vitro methane gas and tannin as it affects digestibility are confirmed by the correlation coefficient values of the seeds (Figs. 1 and 2). The linear reduction in Fig. 2 is an indication that in vitro methane production may have been depressed due to formation of protein-tannin complexes, which may cause reduction in protein solubility. Tannin may depress the fibre digestion and methane gas production either by direct inhibition of cellulolytic microorganisms or by inhibition of fibrolytic enzymatic activity or both. This harmful effect of tannins is alleviated by the thermal treatment of seeds (Sashikala et al. 2015). The trend noticed in Table 3 revealed high fractional rate of gas production in Dioclea reflexa seed, and this could translate to availability of adequate nitrogen and high dry matter intake of ruminants for an improved performance. The highest OMD, SCFA, ME and IVDMD obtained in Dioclea reflexa compared to other test seeds implies that the microbes activities may be enhanced in the rumen and increase nutrients uptake (Chumpawadee et al. 2007; Ramos et al. 2020). The volume of gas produced is a function of relatively high protein quality and tolerable levels of anti-nutrients of the D. reflexa (Figs. 1 and 2) and thus, predicts possible high digestibility, fermentation end-product and microbial protein synthesis of the substrate by rumen microbes, if fed to ruminants. More so, the more percentage methane, the less propionic acid and therefore lower the feed value. The relatively low methane gas observed in this present study is an indication that the seed would not aid methanogenesis (bloat).

\section{Conclusions}

From the foregoing, it is established that the Tomentosa nilotica, Dioclea reflexa and Monodora myristica seeds have the nutritional potentials to be used as supplementary feed ingredients (protein sources) in ruminant ration, particularly during scarcity and or dry season. The processing methods employed had a significant improvement on the chemical composition and in vitro digestibility values. The overall nutritive value of Dioclea reflexa seed was best improved by roasting technique. Further, in vitro degradability study revealed Dioclea reflexa seed to be best among the three seeds and thus, could be harnessed for improved and sustained ruminant production in the tropics. However, it is pertinent to carry out in vivo study to validate this report.

\section{Abbreviations}

ADF: Acid detergent fibre; ADL: Acid detergent lignin; ANF: Anti-nutritional factors; ANOVA: Analysis of variance; AOAC: Association of Official Analytical Chemists; Ca: Calcium; CF: Crude fibre; $\mathrm{CH}_{4}$ : Methane; $\mathrm{CP}$ : Crude protein; DM: Dry matter; EE: Ether extract; FUTA: Federal University of Technology, Akure; GV: Total gas volume; IVDMD: In vitro dry matter digestibility; ME: Metabolizable energy; Na: Sodium; NDF: Neutral detergent fibre; NRC: National Research Council; OMD: Organic matter digestibility; P: Phosphorus; SAS: Statistical Analysis System; SCFA: Short-chain fatty acids; XA: Ash.

\section{Acknowledgements}

The authors hereby acknowledged the Department of Crop, Soil and Pest Management where the seeds were screened and identified.

\section{Authors' contributions}

The concept of the study was conceived, designed and coordinated by ANF. Data collection and data analysis were done by MOA, OBO and ANF. However, writing of the manuscript was done by $\mathrm{OBO}$ and $\mathrm{MOA}$. They are responsible for managing all activities of the experiment. All authors read and approved the final manuscript.

\section{Funding}

Not applicable.

\section{Availability of data and materials}

The data supporting the results of this study are available from Mary $\mathrm{O}$ Adeduntan. However, restriction applies to the availability of the data, which were used under license for the present study and are not openly available. Data are, however, available from the author upon realistic request and with the authorization of Mary O. Adeduntan.

\section{Ethics approval and consent to participate}

Not applicable.

\section{Consent for publication}

Yes.

\section{Competing interests}

The authors have declared that no competing interest(s) exist.

Received: 14 August 2020 Accepted: 27 September 2020

Published online: 08 October 2020

\section{References}

Adeyeye El (2013) Proximate, mineral and antinutrient composition of dika nut (Irvingia gabonensis) kernel. Elixir. J Food Sci Nutr 53:189-196 
Ajibade FO, Adewumi JR, Oguntuase AM (2014) Design of improved storm water management system for the Federal University of Technology, Akure. Niger J Technol 33(4):470-481

Akande KE, Doma UD, Agu HO, Adamu HM (2010) Major anti-nutrients found in plant protein: their effect on nutrition. Pak J Nutr 9(8):827-832

AOAC (2011) Official methods of analysis of AOAC International. 18th edn, Revision 4, In: Horwitz W, Latimer GW Jr (eds) AOAC International. Gaithersburg, Maryland, USA

Babayemi OJ, Bamikole MA (2006) In vitro gas Production and its Prediction on Metabolizable Energy, Organic Matter Digestibility and Sort Chain Fatty Acids of Some Tropical seeds. Pak J Nutr 8:1078-1082

Brown D (2008) Poisonous plants to livestock. Department of Animals Science, Cornel University, USA. www.ansci.cornell.edu/plants/index/html

Chumpawadee S, Chantirakul A, Chantirakul P (2007) Chemical composition and nutritional evaluation of energy feeds for ruminants using in vitro gas production technique. Pak J Nutr 6(6):607-612

Clemens S (2014) Zn and Fe biofortification: the right chemical environment for human bioavailability. J Plant Sci 225:52-57

Eugeniusz RG, Bożena K, Wioleta S, Jan M, Piotr K, Wojciech R, Ewa H (2017) Chemical composition of leguminous seeds: part I - content of basic nutrients, amino acids, phytochemical compounds, and antioxidant activity. Eur Food Res Technol 243:1385-1395

Fievez V, Babayemi OJ, Demeyer D (2005) Estimation of direct and indirect gas production in syringes: A tool to estimate short chain fatty acid that requires minimal laboratory facilities. Animal Feed Sci Tech 123-124(1):197-210

Gerber PJ, Hristov AN, Henderson B, Makkar HJ, Lee C, Meinen R, Montes F, Ott T, Firkins J, Rotz A, Dell C, Adesogan AT, Yang WZ, Tricarico JM, Kebreab E, Waghorn G, Dijkastra J, Oosting S (2013) Technical options for the mitigation of direct methane and nitrous oxide emissions from livestock: a review. Animal 7:220-234

Gorczyca D, Prescha A, Szeremeta K, Jankowski A (2013) Iron status and dietary iron intake of vegetarian children from Poland. Ann NutrMetab 62:291-297

Huang Q, Liu X, Zhao G, Hu T, Wang Y (2018) Potential and challenges of tannins as an alternative to in-feed antibiotics for farm animal production. AnimNutr 4(2):137-150

Heuze V, Tran G, Eugene M, Bastianelli D, Lebas F (2016). Babul (Acacia nilotica).Feedipedia, a programme by INRA, CIRAD, AFZ and FAO. https:// www.feedipedia.org/node/346.

Księżak J, Bojarszczuk J (2014) Evaluation of the variation of the contents of anti-nutrients and nutrients in the seeds of legumes. Biotechnol AnimHusb 30(1):153-166

Martin C, Doreau M, Morgavi DP (2010) Methane mitigation in ruminants: from microbe to the farm scale. Animal 4:351-365

McDonald P (1979) Prediction of In situ rumen dry matter disappearance. Anim Feed Sci Technol 61:73-87
Menke KH, Steingass H (1988) Estimation of the Energetic Fed Value from Chemical Analysis and In Vitro Gas Production Using Rumen Fluid. Animal Res Dev 28:7-55

NRC (2007) Nutrients requirements of small ruminants. National Academy Press, Washington, DC

Omotoso OB (2018) Enhancement of the nutritive value of composite cocoa (theobroma cacao) pod husk for west african dwarf goat production. A PhD thesis submitted in the Department of Animal Production and Health, Federal University of Technology, Akure, Nigeria, p 254

Pal K, Patra AK, Sahoo S (2015) Evaluation of feeds from tropical origin for in vitro methane production potential and rumen fermentation in vitro. Span J Agric Res 13(3):1-12

Patra AK (2012) Enteric methane mitigation technologies for ruminant livestock: a synthesis of current research and future directions. Environ Monit Assess 184:1929-1952

Ramos JT, Flavio PJ, Roberta FC, Guilherme AS, Cristiane BT, Alice HP, Paulo HMR (2020) Effect of tannins and monensin on feeding behavior, feed intake, digestive parameters and microbial efficiency of Nellore cows. Italian J Anim Sci 19(1):262-273. https://doi.org/10.1080/18280 51X.2020.1729667

SAS (2010) Statistical Analysis System Institute Inc. SAS/STAT Programme, Version 9.3. SAS Institute, Inc., Cary, NC, USA

Sashikala VB, Sreerama YN, Pratape VM, Narasimha H (2015) Effect of thermal processing on protein solubility of green gram (Phaseolus aureus) legume cultivars. J Food Sci Technol 52(3):1552-1560

TubielloFN, Salvatore M, CóndorGRD, Ferrara A, Rossi S, Biancalani R, Federici S, Jacobs H, Lammini A (2011). Agriculture, Forestry and other Land use Emissions by Sources and Removals by Sinks: 1990- 2011 Analysis. ESS Working Paper No. 2. FAO, Rome

Vaclavic VA, Christian EW (2008) Essentials of food science, 3rd edn. Springer, New York, pp 107-137

Van Soest P, Robertson B (1985) Analysis of forage and fibrous foods. A laboratory manual for animal science 613. Cornell University, New York, USA

Van Soest PJ, Robertson JB, Lewis B (1991) Carbohydrate methodology, metabolism and nutritional implication in dairy cattle: Methods for dietary fiber, nutritional detergent fiber, and non-starch polysaccharides in relation to animal nutrition. Dairy Sci 74:3583-3597

Wanapat M, Cherdthong A, Phesatcha K, Kang S (2015) Dietary sources and their effects on animal production and environmental sustainability. J Anim Nut 1(3):96-103

\section{Publisher's Note}

Springer Nature remains neutral with regard to jurisdictional claims in published maps and institutional affiliations.

\section{Submit your manuscript to a SpringerOpen ${ }^{\odot}$ journal and benefit from:}

- Convenient online submission

- Rigorous peer review

- Open access: articles freely available online

- High visibility within the field

Retaining the copyright to your article

Submit your next manuscript at springeropen.com 